Сања Ђ. Мацура*

Универзитет у Бањој Луци

Филолошки факултет

https://doi.org/10.18485/ai_zsjoski.2019.2.ch7

821.163.41.09-31 Селенић С.

811.163 .41

\title{
ЈЕЗИК КАО ИДЕНТИТЕТСКА КОМПОНЕНТА ЛИКОВА У РОМАНИМА СЛОБОДАНА СЕЛЕНИЋА
}

Посматрајући језик (идиом) као једно од идентитетских обиљежја, на примјеру ликова из романа Слободана Селенића се прати удио промјене или очувања језика (идиома) при идентитетској трансформацији у сусрету с Другим. Два су основна типа односа према сусрету с Другим и с новоуспостављеним друштвеним односима - један почива на тврдокорном задржавању и интензивирању постојеће идентитетске вертикале (посебно кроз идиом), а други на њеној убрзаној трансформацији (која се опет, понајприје, огледа у идиому или у језику у случају сусрета и потребе за асимилацијом са страном културом и њеним носиоцима идентитета).

Клучне ријечи: Слободан Селенић, идентитет, језик, идиом, лик, трансформација

1. Слободан Селенић написао је седам романа, ${ }^{1}$ од којих је шест довршених, а а један је објављен постхумно. Од свог појављивања до данас сваки од тих романа био

\footnotetext{
* sanja.macura@flf.unibl.org

1 Романи: Мемоари Пере боїала (1968), Пријайељь са Косанчићевоі вениа (1980), Писмо-їлава (1982), Очеви и оци (1985), Timor mortis (1989), Убисӣво с ирреgумиштьајем (1993) и Малајско луgило (2003).
} 
је изазован за књижевне критичаре чије су рецепције, међусобно различите, сезале од потпуног одобравања до строгог и негативним тоновима обојеног критицизма. Истовремено хваљен и куђен, из књижевних и политичких разлога, овај писац је у својим романима створио свијет унутар којег су се сусрела и сукобила различита поимања свијета и одраза слика тог свијета, преломљена кроз специфичне ликове и њихове судбине.

Имајући на уму вријеме у којем је рођен и одрастао, те стасавао и чинио прве књижевне кораке, а с обзиром и на окружење из ког је поникао, ${ }^{1}$ чини се сасвим природним што је стална тему његових романа питање постојања више истина, једне праве, истините истине и друге историјске, договорене, изрежиране, сурогат истине. ${ }^{2}$ Управо је бављење овом, у свим тоталитарним режимима осјетљивом и недопустивом темом, „коштало” Селенића који је пао у немилост Партије и њене бирократије. Већ је својим првим романом, Мемоари Пере Боїаља (1968), дирнуо у тему партизанске буржоазије, те иако су га на велика врата својим критикама увела водећа пера тадашње српске критике Борислав Михаиловић Михиз (1968) и Петар Џаџић (1968), Селенић се нашао под политичким притиском. И својим другим романом, Селенић је зашао у просторе тадашње табу теме, јер се у рукопису Дечја йосла, понуђеном за штампу 1972. (када је његово објављивање забрањено) и касније објављеном под насловом Писмо/їлава (1982), бавио темом Голог отока. Након

1 Слободан Селенић је потицао из породице београдских интелектуалаца. Његови родитељи, Саво и Вера, били су професори у приватној гимназији, коју су и водили. Мајка му је била кћерка православног свештеника. Отац и тетка по мајци, Богданка Сека Подунавац, скончали су живот од „партизанске руке” - Селенићевог оца су 1944. године стрељали партизани, којима је ишао да се придружи, а тетка је убијена у вријеме Информбироа.

2 О теми истине/истина у Селенићевим романима в. Мацура 2011. 
невоља у вези са објављивањем другог написаног романа, услиједили су: Пријатиельи с Косанчићевої вени,а, Очеви и оци, Timor mortis, Убисӣво с йреgумишльајем и Малајско луgило, романи за које је писац добио престижне књижевне награде, ${ }^{3}$ и који с га сврстали у врх српске прозе друге половине прошлог вијека. Посебна атрактивност свих ових издања лежи у њиховој тематско-мотивској равни која је неодвојив, чак базични сегмент Селенићевог укупног поетолошког израза. Окренутост темама историје, истинитости истине, дошљака, цивилизацијског пораза српске грађанске класе након Другог свјетског рата, те положаја појединца у ковитлацу историјских догађаја који га измјештају из дотадашњег познатог система без могућности да реагује, условиле су примарни хронотоп унутар којег се овај писац суверено књижевно кретао.

Квалитет Селенићевих романа изњедрио је немали број стручних и научних радова о њима, чији су аутори писали како о појединачним остварењима, тако и о цјелокупној његовој поетици, узимајући као полазиште први роман и на основу њега истражујући приповједачку пишчеву поетику у различитим њеним слојевима. Тако Александар Јерков посматрајући Селенићеве романе напоредо с дјелима Светлане Велмар Јанковић, Бошка Петровића и Александра Тишме, и поредећи га са дјелима која „ће се доцније препознавати и читати спрам постмодерне поетике" (Данило Киш, Борислав Пекић, Мирко Ковач), исправно закључује да је у Селенићевим романима „тематска преокупација снажнија од испитивања могућности нових књижевних поступака и техника приповедања”, те да „гледано у целини

3 Октобарска награда града Београда (1968); НИН-ова награда за најбољи роман године (1980); награда југословенске критике „Меша Селимовић” (1980); награда Народне библиотеке Србије за најчитанију књигу (1981); награда сарајевске „Свјетлости” (1990); признање Народне библиотеке Србије (1995). 
нова поетика није основна одлика" његовог књижевног опуса (132-133). Петар Џаџић (1989) као аутор једног од свеобухватнијих текстова о Селенићевим романима, у којем је обухватио појединачне и упоредне анализе његова четири романа (Мемоари Пере Боїала, Писмо/ілава, Пријайель и Очеви и оци), осим што попут Јована Делића (2004: 107-118), примјећује сталност хендикепираности примарног наратора, издваја и питања „Ко су? Ко сам?”, те „Ко сам био?” и „Ко су били?” (1989: 282) као фундаментална за све нараторе у Селенићевим романима, уочава и сталност одсуства реалног стварног повјерљивог Другог, и појаву његове компензације у имагинацији, те анализира преклапање и раздвајање наратора и времена нарације, што даље развија кроз анализе ликова и њихових поступака. Пишући критику петог Селенићевог романа (Timor mortis), Предраг Палавестра (1991) је зашао у поетичку анализу свих његових дотадашњих романа пишући о сваком појединачно, те тражећи и налазећи паралеле које неке међу њима повезују тематски, организационо или на неки други начин, те закључио да је Селенић превасходно писац „поетике грађанског пораза”, односно онај који међу првима проговара о унутрашњем раслојавању партизанске „класе” и о њеној трансформацији у сопствено наличје стављајући тежиште на припаднике предратне грађанске класе која се у додиру са непознатим растаче, неспособна да се асимилује. У свом већ споменутом тексту Јован Делић полази од тога „да је Слободан Селенић изузетно заинтересован за питања поетике и језика и да се његова поетика може ишчитати изнутра, из самих романа" (2004: 107), те трагајући за поетичким начелима кроз интерпретацију износи закључке апликативне и на друге романе овога писца, истичући „наглашено” иронизовање и релативизовање истине, отворену полемику са соцреалистичким насљеђем путем аутоцитатности, помјереност нараторовог виђења свијета условљеног хендикепираношћу, „разговор 
мртвих, или с мртвима” (112), карактеристичну организацију времена које је згуснуто и сложено као шпил карата и простора који је затворен у стварном, а отворен само у доживљајном времену, те „наглашена склоност ка гротесци” (117). О Селенићевим романима је са становишта наративне поетике писала и Владислава Рибникар (2004), пошавши од тематско-мотивске равни у којој препознаје мотиве „људске усамљености, изолованости и тешкоћа на које се наилази у трагању за комуникацијом и разумевањем”, затим размишљања о „релативности истине”, те „крхкост сећања, непоузданост наших знања о прошлости, потреба за испуњавањем пукотина и отклањањем наслага идеолошких интерпретација" (204: 91). Кроз сукцесивну анализу романескног Селенићевог опуса, Рибникар је закључила да „сви Селенићеви ликови мисле као да приповедају”, „да су сви они затворени у свет властитих наративних истина”, те „да су његови приповедачи непоуздани сведоци". (2004: 93-95) Овај кратки пресјек рецепције Селенићевих романа ${ }^{4}$ завршићемо констатацијом да су готово сви проучаваоци књижевности који су се бавили прозом овога писца сагласни у томе да опус који је он оставио иза себе иде у ред најинтересантнијих и најчитанијих у нашој новијој књижевности, да се ради о писцу са опсесивним кругом тема, који не признаје табуе и који историју, како далеку тако и недавну, види из себи својственог угла. Ситуирајући своје ликове у предратни, ратни и поратни Београд, ${ }^{5}$ донио је у српску књижевност новине у композицији, тематици и начинима њене обраде. ${ }^{6}$

4 Више о рецепцији романа Слободана Селенића види у Мацура 2011.

5 Ради се о Другом свјетском рату, о.п. C.M.

6 Овакав вредносни суд био је споран само у перима оних који су као догмате стајали на капији кроз коју су право пролаза имали „подобни” писци, који су се „клањали” партијској истини. На срећу, таквих је било мало. 
2. И поред респектабилних текстова написаних о Селенићевим романима, остао је отворен простор за њихова нова читања и интерпретације која би пошла од тога да одређене феномене, теме или теоријске категорије прати кроз цјелокупан опус. Осим питањима истине и памћења, овај писац се тематски бавио и односом између старог и новог, традиционалног и модерног, прошлости и садашњости, дошљака и старосједилаца, преображавања или конзервисања одређеног културолошког обрасца, пораза грађанске класе и укорјењивања новог устројства, српских и хрватских интереса etc. Посматрајући традицију као круг обичаја и вјеровања која неку људску заједницу повезују са њеном прошлошћу, и посматрајући културу као простор у којем индивидуа покушава да организује елементе који теже ка ентропијској дезорганизацији система у којем дјелује, Селенић се литерарно бавио и питањима потребе и потраге за комуникацијом као човјекових покретачких елемената, укрштајући ову раван с другим темама и мотивима, превасходно питањима односа појединца и културе, бића и језика, те њихове међусобне повезаности и условљености која одређује идентитет сваког од својих ликова. А о начину на који их је стварао рекао је: „Често имам у виду неку одређену личност када стварам лик у роману. Некада се из прототипа улије у лик више, а некад мање стварних особина, међутим, прототип и лик никада нису идентични." (Селенић 1995: 200) Необичност и понеку бизарност поступака својих ликова образлагао је на сљедећи начин: „Ако је свака од личности у једној својој димензији смешна, извитоперена, примитивна, ја сам се увек трудио да свакој од њих дам и другу димензију преко које ће показати и своју људску и трагичну страну." (Селенић 1981: 23) Трудио се, док је писао, да књига буде „испричана језиком двоје људи који не разумеју призор који посматрају, и зато га виде боље и оштрије у поје- 
диностима од оних који су на њега огуглали.” (Селенић 1985: 32) Притом је тај „језик” (у значењу идиома) којим ликови-наратори приповиједају њихово идентитетско дистинктивно обиљежје. Он их одређује личносно, те сталешки, социјално, он је компонента које се ликови у грчевитој борби да се одупрупромјенама чврсто држе или га се одричу трансформишући га када су у ситуацији да мијењају свој статус на друштвеној љествици. Код Селенићевих ликова језик (идиом) је нераскидив дио личног идентитета. Ако идентитет посматрамо као нешто што се „повезује са националном и културном припадношћу”, као оно што „омогућава човеку и друштвеној заједници да мисле о себи у склопу одређених карактеристика, да мисле о индивидуалној и колективној припадности”, као „саставни део друштвеног и националног живота” чија се „основна карактеристика” састоји „у томе што омогућава стабилност мишљења, понашања и оријентација”, jep „реч је о осећају и свести о сопственом JА” - онда и језик видимо као „инвентар једне културе; посредством језика откривамо начин мишљења, вредносне и прагматичне оријентације припадника културе, однос према времену, природи, свету... језик повезује припаднике једне културе, али их и разликује према статусном, професионалном, регионалном, семантичком критеријуму". (Аврамовић 2015: 7-8) Ово постаје посебно очигледно при сусрету „наше грађанске и комунистичке традиције. Ту су сплетени у чвор многи сасвим лични и сасвим општи моменти живота: породичне околности, историјске заблуде, утемељење у самопорицању..." (Бошковић 2015: 41) Управо се у зони или преидентификације или диносауризације идентитетског код Селенићевих ликова језик (идиом) издваја као личносна компонента која се издваја из мноштва осталих.

Два су типа оних ликова који теже ка преидентификацији. Првом припадају они који покушавају да 
се прилагоде или асимилују у оквире народа који није њихов говорећи језиком који им је стран (Енглескиња Елизабета у Београду, Србин Стеван Медаковић у Енглеској, Енглескиња Рашела у Београду, Албанац Истреф у Београду). Очигледан примјер свакако су писма која Енглескиња Елизабета (Очеви и оци) на српском језику (који учи) пише својој рођаки Рашели (чак и након њене смрти), а у којима се налази управо она раван у којој се преламају различите визуре и покушаји успостављања комуникације са туђом традицијом, те њеног прихватања и преношења на потомство. У овом роману, Селенић се послужио језиком како би тим другачијим Елизабетиним језичким изразом показао немогућност простог пресликавања једне традиције (српске) на шаблон који је од самог рођења успостављен у припаднику друге традиције (енглеске), а обрнуту ситуацију је предочио кроз Стеваново учешће у племићком лову у Енглеској. Док Елизабета на „свом” српском језику који учи чинећи напор да се прилагоди средини у коју се удала покушава да објасни значење лексема „посестрима” и „сарма”, Стеван енглеским племићима објашњава шта за босог српског пастира значи кад се крава први пут „пробалега” у хладном јутру, па та балега послужи за гријање промрзлих ногу. И један и други покушај дјелују комично, Елизабетин српском читаоцу романа који кроз њен српски језик сагледава дио себе, а Стеванов слушаоцима у роману који су одушевљени његовом способношћу имагинације и нарације којом их је насмијао, јер оно о чему им је приповиједао, свакако, не може да буде истинито. Карактеристике ликова који су дошљаци из других народа и земаља и желе да се асимилују интересантне су управо због тога што покушавају постати оно што нису и никако не могу да буду. Стеван у Енглеску доноси оно чиме га је кроз васпитање задојила Нанка, а што му не помаже да се носи са ситуацијом у којој се нашао. Само, он је попут 
камелеона, и врло брзо схвата начин прилагођавања средини, како кроз понашање, тако и кроз језик. Његова трагика је у томе што га енглеска средина у којој студира мијења, тако да при повратку у Србију више не припада ниједној од њих - није успио да постане Енглез, а није остао ни типични Србин, тим више што се оженио странкињом, Елизабетом. Њена улога као дошљака је специфична, јер се труди да се што успјелије уклопи у свијет Београда у којем се обрела, учи српски језик и обичаје (који су јој страни, нелогични, а некад и одбојни). Чак са својим сином прича на њој страном, српском језику како би од њега у Србији направила Србина, подносећи тиме врхунску жртву прилагођавања, која матерњи језик мијења за очев, и то кроз уста мајке. Само, ни та њена врхунска жртва у преидентификацији путем језика не бива довољна, јер је њен син Михајло право „Енглешче”, бијеле пути, риђ, другачији појавом и манирима од свих дјечака Срба који га окружују, што на крају и доводи до трагичног исхода његовог живота. Рашела је у другачијој ситуацији. Она је из Београда, удала се у Енглеску, али је Јеврејка, те сама каже да ниједну од двије домовине не осјећа својом. Исто како је живјела у Београду, прилагодила се без проблема и животу у Енглеској, јер су обје те земље за њу дијелом стране. Код ње слика о Другом и слика о себи чине јединство унутар Јаства, које је истовремено и актант и пацијенс. Албанац Истреф веома рано улази у процес трансформације којим пигмалионски руководи Владан који код њега мијења све, од језика и идиома, преко појавности и манира, до начина размишљања и аутоимажа. Касније се трансформисани Истреф сусреће/ сукобљава с властитом прошлошћу виђеном очима Другог (Владана) путем рукописа који на видјело износи примарног Истрефа потиснутог и готово заборављеног унутар Истрефа самог. То раслојавање унутар лика кулминира његовим гнушањем од властитог сина Башкима 
у којем препознаје Владана Хаџиславковића не толико у стилу и лексемама колико у слици свијета која се зрцали у Башкимовом идиому. Истицањем супротности и представљањем ликова тако да један јесте оно што други није и то на начин да је оно што лик није саставни дио Другог са којим тај лик силом прилика живи и сучељава се, ствара се ситуација у којој се кроз инауграцију слике о Другом истовремено дезинтегрише слика о себи. Дезинтеграција слике о себи почива на томе да се Ја огледа и пројектује преко доживљеног Другог и на тај начин се неповратно мијења.

Другу групу ликова који пролазе кроз вољну трансформацију идентитета која се огледа и у језику (идиому) чине они који остају унутар свог националног корпуса, али се на неки начин „помјерају” у социјалном или сталешком смислу, па је преидентификација нека врста карте или улазнице у свијет који садржи оно чему се тежи или оно што обезбјеђује опстанак у жељеним оквирима (Перо Богаљ, Драга, Крсман, Јелена Панић). Драга (Мемоари Пере боїала), кћерка миниситра кральевске влаgе која је уместио gа остиане у свом колеиу, gошла gа ииче „Пела иукела” белим кречом йо иррљавом зияу (Селенић 2004: 97-99) се са новим, поратним системом живота сусреће као дјевојчурак. Иако је поријеклом из самог врха предратног грађанског друштва, образована, начитана и билингвална, она покушава да се уклопи у новонасталу ситуацију, учи нови, партизански „језик” и допушта да је преваспитава Перо Богаљ. Она сатима „прорађује” комунистичку литературу трудећи се да трансформација за коју је свјесна да јој обезбјеђује егзистенцију буде што потпунија, али истовремено она не може да заволи козарачко коло и да му у себи уступи мјесто које припада

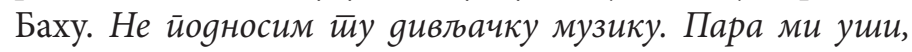
ужасна је, Перо! Ја знам gа ірешим, знам gа нисам у ираву, али ја волим Баха (Селенић 2004: 145). Остаци старог 
васпитања у њој су дубоко укоријењени и није их могуће избрисати. Њено прилагођавање рјечнику и облицима понашања, те менталитету побједника, партизана, неуспјешно је. Када постане господарица у дому Прокића, претвара се у малограђанку која све остатке старог мијења новим, што сјајнијим, блиставијим. Њена језичка трансформација је двострука. Прво усваја реторику ратних побједника, а онда се враћа свом примарном идиому који хиперболише до нивоа кичераја. За разлику од ње, Злата (Писмо/ілава) покушава да своју асимилацију која значи и егзистенцију изнивелише тако да током ње не изгуби право на употребу идиома који је дио његог грађанског идентитета. Умјесто властите трансформације, она покушава да своје Ја кроз брак амалгамише са припадником тог новог, другог свијета (Радиша) и изгради бар привид живота након Макијеве смрти. Ова два романа дају слику атмосфере која влада у поратном Београду, ниво промјена унесених у правила опхођења, говорења, облачења и понашања, те њихов утицај на већ постојеће, грађанске идентитете. Слика партизанског уласка у Београд и њиховог активитета да све измијене и организују на свој, другачији начин, у роману Писмо/ ілава дата је у бројним нијансама - од поријекла ликова, преко њиховог рођења, дјетињства, одрастања, образовања, начина и степена социјализације, промјена које су се у окружењу десиле и њиховог утицаја на појединачне људске судбине. Носиоци предратног грађанског идентитета су Максимилијан и Злата, док је Радиша представник новоуспостављеног идентитета ратних побједника. Трансформација идентитета коју трпе сви актери овог романа.је додатно усложњена тиме што је Радиша још у раном дјетињству „смјештен” у исти оквир у којем одрастају Маки и Злата, те није, попут Милоја или Пере богаља, Варварин који скрнави савршену слику, што постаје усуд ликова у овом роману - нико нема право да одлучује о 
својој судбини, јер је она свима наметнута. Контрапункт између Радише (који је дијете сељака пијанца, вашљив, рањав, гладан, запуштен, али навикао да се у животу сналази и процјењује сваку ситуацију) с једне, и Макија и Злате с друге стране, основа је приказивања разлога за пропаст грађанског друштва. У овом дјелу Селенић иде корак даље од романа Мемоари Пере Боіаља дајући умјесто слике декаденције панораму „обичног” живота успјешног „новог човјека”, додуше гротескну јер је приказана кроз Златину визуру. Kag Раguшини йријайељи gођу коg нас, или ми одемо коg них, неколико gана не моіу gа савлаяам іорушииу у мом ирреосеитьивом друшиивеном сйомаку... Прирояно је шйо се ја у овим ириликама осећам као „укочанени клий кукуруза”, како је йо gобро јеgном ойисао Раgиша. Али је и Радиша између gве вайре: йойребе gа мени објасни юих, и жеље gа мене објасни юима, ийо му наравно, нарочит̄о ово яруі̄о, не йолази за руком. А домаћини посматрају Злату стирашећи ме се

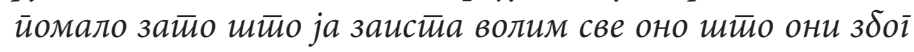
свої ӣоложаја и ранїа уз оййор и тажни йоgсмех морају gа page. (Селенић 2002: 240-243) Основне карактеристике „сједељки” успјешних градитеља комунизма, нове елите друштва оптерећене су за њих неудобним одијелима и уским хаљинама од ламеа, сталном потребом за посједовањем „финих” пића док им се пије само ракија, једу брда меса, сира и пршута, уз обавезну завичајну причу унутар које из увјежбаног новоуспостављеног квазиграђанског идиомског оквира „искачу” лексеме које су изразито руралног поријекла и значења. У њима се једини остатак некадашњег стварног грађанског друштва, Злата, осјећа потпуно изопштено, јер на свом примарном „језику” истински може да комуницира само са мртвим Макијем. Злата својим дишућим дијелом свога бића и идентитета живи у сјећању на оно некада које бар у идиому грчевито покушава да сачува, док својим анестезираним дијелом 
живи окружена оним у шта није могла да се трансформише, да би на крају излаз нашла у својевољној смрти. У овом роману Селенић је уз апострофирање језика (идиома) као примарног сегмента идентитета, симболично укрстио слику Радише, који је сав жилав, чворуїавих

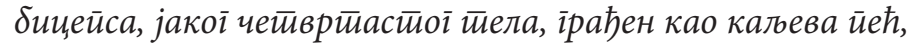

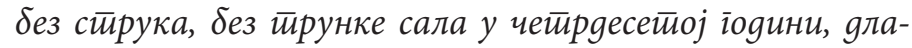
кав, иијан (Селенић 2002: 50) и Макијевог духа, који као авет лебди над Београдом. У њему је чак и Златин и Радишин син за њу потпуни странац с којим не може да нађе никакав заједнички именитељ, јер исти је као отац, генетски предиспониран представник онога чега се Злата гнуша. За разлику од Злате, Јелена Љубисављевић

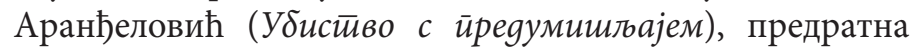
београдска госпођица, након завршетка због очуховог хапшења бива принуђена да се приближи оличењу свега што презире - ратном мајору Крсману. Све око ње сабласно је говорило громогласним шапатом: Прошло ваше, Аранђеловићи! (Селенић 2002б: 179) Несналажење припадника предратне грађанске класе у сусрету с новим нормама понашања и говора, нарочито зорно приказаним у дијалозима између Јелене и Крсмана, Селенић је осликао кроз сукоб на нивоу језика, лексике, и указивања на јаловост супериорности образоване господе која не могу да се снађ), јер је њихова супериорност (коју само сами себи признају) кратког даха - она капитулира пред снагом и упорношћу ратних побједника и кулминира у Јовановој и Јелениној „Игри књижевних подвала”, базираној на исмијавању ортоепских неправилности уочених у окружењу. Нова игра с којом се сусрећу нема правила која њих двоје могу да разумију. Они које је Јелена донедавно називала „репатом стоком” постали су нови власници свачијег живота, па и њеног и Јовановог, јер одлучују о свему и нико у томе не може да их заустави. Јелену одлазак у Париз са делегацијом коју преводи јер нико од 
њених чланова не говори ниједан „језик” осим свог завичајног, доводи до закључка који јасно осликава ситуацију у којој се нашао њен слој - ТО JE CBET, JOBAHE, У КОЈИ ЋЕ КРСМАНИ УЋИ ЛАКО, А МИ, ИЛИ УЗ ЊИХ, ИЛИ НИКАКО. (Селенић 2002б: 205) Ова њена реченица упућена Јовану у писму које показује праву слику Европе након рата, односи се како на Јелену, тако и на Драгу и Злату које у ковитлацу промјена на које нису могле да утичу полако одумиру у времену које је значило враћање точка цивилизације уназад, истовремено покушавајући да се колико морају прилагоде трансформишући се а истовремено се ослањају на свој примарни идентитет, на идиом из дјетињства који је њихово основно дистинктивно обиљежје. Политички и језички жрвањ побједника смрвио је све - Драгу, Злату, Владана, Стевана, Елизабету, Михајла, Јелену и Јована, јер нико од њих чак ни у случају преидентификације и привидне промјене језика (идиома) није могао из себе да избрише примарно Јаство. И лик Крсмана Јакшића припада групи ликова који у неком тренутку свога живота посежу за преидентификацијом, у његовом случају - путем промјене говорног идиома. Он то не чини због тога што треба да се асимилује с ратним побједницима. Напротив, он је побједник и репрезент свега онога што затире српску грађанску класу након Другог свјетског рата. Али, оно што он јесте је да је заљубљен у Јелену, грађанку, која га на почетку њиховог познанства игнорише. Носилац одреднице која каже да је у рату убио хиљаду људи и обљубио хиљаду жена дословно капитулира пред буржујком Јеленом која је, социјално, управо оно против чега он треба да се бори. Такав покушај вољне трансформације припадника нове елите јединствен је примјер у Селенићевом романескном опусу.

Посљедњу групу чине они ликови који се чврсто, „диносаурски” држе своје идентитетске вертикале, 
појавно углавном ослоњене на језик (идиом), без обзира на све околности које их окружују. Међу њима се истичу Танкосава, Владан, Нанка, Старац, Којовић и Јован. Сви они су, иако различитог поријекла, слични у једном - без обзира на то да ли су дошли са села у град или су у свом граду и дому постали странци након промјена које је донио крај рата, сви они настављају да живе бар сурогатом својих дотадашњих живота, као да свијет око њих и промјене у њему не постоје. Танкосаве и Нанке ликови су старовременских жена које се, наизглед, током цијеле приче којој припадају не мијењају. Обје почивају на епском принципу, а свијет доживљавају из угла народне традиције. У Нанкином лику садржан је узалудни покушај очувања онога што је пред налетима страног, туђег, већ промијењено, труд да се од мушког члана породице, малог Стевана, направи оно што „има да личи на нешто” - не смем йлакайи. То Нанка не дозвольвва. То није срйски и мушки, а ја йре свеі̄а морам битии Србин и мушкараи. (Селенић 2006: 10). Као и сваки други конзервативни, „тврдоглави” изданак једног национа који улази у процес иреверзибилне трансформације која је видљива у наглом напуштању традиције и усвајању туђих образаца, Нанка остаје усамљени примјер патријархалне хероине која не одступа ни корака у својим увјерењима. Животи је у Нанкиним ирричама био суров иррема срйском нарояу, али $\delta а ш$ зайо лей. (Селенић 2006: 34-35). За њу ничега важнијег од српског језика нема, и то не било којег српског језика, него оног који се учи из народних епских пјесама и који идентитетски и по њеном дубоком увјерењу неизбрисиво у дјечаке укорјењује све на чему национ којем припадају мора да почива. Иако је Нанкин пандан Танкосава (Мемоари Пере боїаља), међу њима постоји битна разлика, јер је Нанка статичан лик, а Танкосава тежећи да се ништа не промијени пролази кроз трагичну трансформацију прво односа према мужу, затим према сину, 
и на крају према самој себи. Оно што Нанку „сачува” од исте врсте трагике је деменција која је спашава од патње.

Било каквој промјени опире се и Јован (Убистиво c ирреумишљајем), чије је инсистирање на устаљеном поретку ствари који више није могућ с једне стране преточен у сексуално насиље над Јеленом, а с друге је дубоко укотвљен у супремацију онога што је за њега језик цивилизације насупрот језику репатих, примитивних дошљака-ратника пред којима одбија да капитулира. Мотив убиства није чест у романима овога писца, али је Јованово убиство Крсмана и самоубиство које је услиједило приказано као пуцањ у промјену, у ново, другачије, из његовог угла примитивно, нечисто и нецивилизовано.

Два су мушка лика који младе истраживаче прошлости причом и ријечима воде кроз лавиринт непознатог - Старац (Timor mortis) и господин Којовић (Убистиво с иреgумишљајем). Старац је интелектуалац, Србин који је читав свој активни радни вијек провео у Хрватској, а господин Којовић је, иако интелектуалац, живот након рата провео тихо, готово непримјетан. Старац жели да његово име остане запамћено, забиљежено у историји, те приповиједајући Драгану плански ствара одређену слику о себи, која се на крају показује као лажна. $\mathrm{OH}$ језик и причање користи као алатку за стварање илузије властите битности. За разлику од њега, господин Којовић нема скривених интенција. Све што жели јесте да помогне Булики, унуци своје давнашње пријатељице, и труди се да буде што објективнији када приповиједа. Он си ирича своје. Полако. Нема йодразумевана - свака реченииа с йомметиом, ирироком и свим иииама и бииама. Нема „као”... Каgа навоgи нечије речи, мень реіистиар на gуімейари. Глуми. Шмекер. Ужива. Баш іа бриїа за време. Уживам и ја. (Селенић 2002б: 10-11). Којовић је пријеко потребна спона између два свијета, једног поратног са средине прошлог вијека, и другог, ратног, из његове 
посљедње деценије. У готово осамдесет година живота није доживио озбиљну трансформацију, а све што се у вези с њим измијенило је адреса и квадратура животног простора. Да би Булики и Богдану приближио давне догађаје, Којовић покушава да објасни и дочара трансформацију система вриједности пријератне у систем вриједности послијератне Србије. При томе готово да не постоји шум у комуникацији између Булике с краја двадесетог вијека (која за себе каже да је „вуковац” који „пише као што говори”, а говори како год жели, потпуно жаргонски) и Којовића који говори управо онако како би требало писати (потпуно у складу с тековинама школе реторике из сремскокарловачке гимназије). У овом роману питање идиома као идентитетске компоненте изразито је доминантно. Којовић, на примјер, Булики и Богдану објашњава шта су лексеме „партизан”, „мајор”, „студент” или пак „револуционар” значиле у Београду 1945. и пореди их са конотативним слојем који имају пола вијека касније, али им истовремено објашњава и значење лексема које деценијама нису у употреби, попут „тасовац”, „ОЗНА”. Немогућност потпуне, проходне комуникације је, као и у претходним романима, ситуирана у подручју комуникације између вршњака (Булика и Богдан) који потичу из различитих микрохабитуса, који су, иако припадници истог народа, стасали на различитим традицијама, идиоми су им различити иако је језик (српски) исти, а различит им је и поглед на свијет. Ипак, за разлику од свих претходних Селенићевих романа, то двоје вршњака се истински заљубљује и та заљубљеност бива достатна да разлике буду премошћене. Оно што није било могуће премостити јесте мотивска константа овога писца која почива на немогућности постизања личне среће у злехудом времену.

3. Посматрајући језик (идиом) као једно од основних идентитеских обиљежја, на примјеру романа Слободана 
Селенића анализиран је удио промјене или очувања језика (идиома) при идентитетској трансформацији ликова у сусрету с Другим, са тектонским друштвеним поремећајима или са личним жељама за досезањем новог нивоа на друштвеној љествици. Два су основна типа односа већине Селенићевих ликова при сусрету с Другим или с новоуспостављеним друштвеним односима. Први почива на покушају трансформације примарног идентитета (која се код међуодноса са припадницима истог национа понајприје огледа у идиому, тј. у језику у случају сусрета и потребе за асимилацијом са страном културом и њеним носиоцима идентитета. Други тип ликова репрезент је тврдокорног задржавања па чак и интензивирања постојеће идентитетске вертикале, посебно кроз идиом, кроз апострофирање традиције, обичаја, вјеровања. Показује се да у Селенићевим романима не постоји „срећна” трансформација идентитета лика, чак ни када је она жељена и неопходна, јер примарни идентитетски слој увијек остаје доминантан, чак и када то није видљиво све до посљедњих тренутака у животу, што је посебно случај код ликова који или изврше самоубиство, или свјесно одлазе у смрт.

\section{Литература}

Аврамовић 2015: 3. Аврамовић, Борба за идентитет српског језика, Узданица, XII/1, 7-19.

Бошковић 2015: Д. Бошковић, Имагинарна Европа, Узgаница, $\mathrm{XII} / 1,49-54$.

Делић 2004: J. Делић, Поетика и интерпретација. „Мемоари Пере Богаља" као полазиште за истраживање приповједачке поетике Слободана Селенића, у: Сйоменица Слобоgана Селенића, САНУ Научни скупови, књ. CVII, Одељење Језика и књижевности, књ. 16, Београд, 107-118. 
Jerkov 199: A. Jerkov, Od modernizma do postmoderne, PrištinaGornji Milanovac.

Кољевић 2003: С. Кољевић, Сусрети две културе у делу Слободана Селенића, Кғижевни маїазин, јул-август, год. III, бр. 25-26, 10-14.

Кољевић 2004: С. Кољевић, Сусрети српске и енглеске културе у делу Слободана Селенића, у: Сӣомении, Слобоgана Селенића, САНУ Научни скупови, књ. CVII, Одељење Језика и књижевности, књ. 16, Београд, 2004, 125-137.

Мацура 2008: С. Мацура, Поейика романа Слобоgана Селенића, Кюижевна истиорија, Београд, 134-135, XL, 167-178.

Мацура 2010: С. Мацура, Типологија ликова у романима Слободана Селенића, Филолої, II, 100-114.

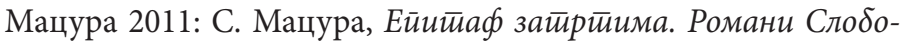
gана Селенића, Лакташи: Графомарк.

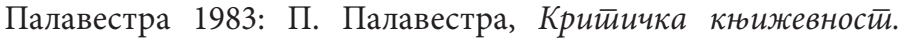

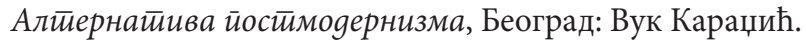

Палавестра 1990: П. Палавестра, Поетика грађанског пораза. Романи Слободана Селенића, Книжевне новине, 15.3.1990, год. XLIII, бр. 794, 4.


олоіије (Кюижевне иеме IX), Београд: Српска књижевна задруга.

Палавестра 1995: П. Палавестра, Крийичке расӣраве, Београд: Просвета.

Палавестра 1996: П. Палавестра, Исӣорија моgерне срӣске къижевностии, Београд: Српска књижевна задруга.

Рибникар 2003: В. Рибникар, Од интроспекције до књижевног текста, Кюижевни маїазин, јул-август, год. III, бр. 25-26, 6-9; Исто у: Сӣоменииа Слобоgана Селенића, САНУ Научни скупови, књ. CVII, Одељење језика и књижевности, књ. 16, Београд, 2004, стр. 91-97.

Selenić 1981: S. Selenić, Roman na dva kata, [NIN-ova nagrada za roman Prijatelji], razgovarao Dušan Stanković, Rad [list Saveza sindikata Jugoslavije], 13.3.1981, god. 37, 23.

Селенић 1981a: С. Селенић, Доба самодовољности романа, Кюижевне новине, 5.11.1981, год. XXXIII, бр. 635, 6-7. 
Селенић 1985: С. Селенић, Опаке српске илузије, зашто Слободан Селенић у свом новом роману „Очеви и деца” највише критичке енергије усмерава на мит о српској виспрености у политици, разговарао Теодор Анђелић, НИН, 25.8.1985, 32-34.

Селенић 1987: С. Селенић, Роман и историја, Кюижевне новине, 15.5.1987, год. XXXVIII, бр. 732, 1.

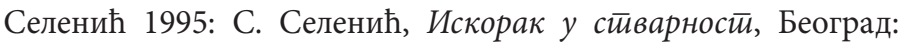
Просвета.

Селенић 2002: С. Селенић, Писмо/їлава, Београд: Просвета.

Селенић 2002а: С. Селенић, Timor mortis, Београд: Просвета.

Селенић 2002б: С. Селенић, Убисииво с ирреgумишьајем, Београд: Просвета.

Селенић 2003: С. Селенић, Малајско луgило, Београд: Просвета.

Selenić 2004: S. Selenić, Memoari Pere Bogalja, Beograd: Prosveta. Selenić 2004a: S. Selenić, Prijatelji, Beograd: Prosveta.

Селенић 2006: С. Селенић, Очеви и оци, Београд: Просвета. Џаџић 1968: П. Џаџић, Чисти и прљави [Слободан Селенић, Мемоари Пере Богаља, 1968], НИН, 17.11 1968. год. 18, бр. 932, 13. [Прештампано у: П. Џаџић, Критичке и оілеgи. Београд: СК3, 1973. 151-154.]

Џаџић 1989: П. Џаџић, Свет промена и враћања, романи Сло-

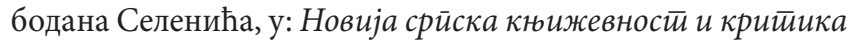
иgеолоіије, Предраг Палавестра ред., Научни скупови CAHУ, књ. XLVI, Одељење језика и књижевности, књ. 10, Београд-Ниш, 97-102.

Џаџић 1995: П. Џаџић, Homo Balcanicus, homo heroicus I, Сабрана дела, VIII том, Београд: Завод за уџбенике и наставна средства.

Џаџић 1996: П. Џаџић, Слободан Селенић, Книжевности, год. XLIX, књ. C, 3-4, 318-323. 
Sanja Macura

\section{A LANGUAGE AS A COMPONENT OF CHARACTERS IDENTITY IN NOVELS OF SLOBODAN SELENIC}

A language (idioma) is one of the basic characteristics of one's identity. As such, it has been analyzed in novels of Slobodan Selenic i regard of its transformation or preservation during changes of characters' identities in their meeting or colliding the Other during complex social and political events or in occasion of character's wish ti rise on the social levels. Majority of Selenic's characters can be seen in one of two major groups in regard to their relation with newly established social order which asks for transformation of one's identity, including the language (idioma). Characters in the first group try to transform their primal identities. If they collide with members of the same nation they change idioma, but if they have to assimilate with member of some foreign nation they change their language. Characters in the second group are hard liners who strongly preserve their identity or even strengthens it especially in regard to idioma, language, tradition, customs, beliefs etc. In Selenic's novels there is not a single "happy" transformation of any character's identity, whether it is wanted or desired, because a primal identity remains a dominant one till the last breath.

Key words: Slobodan Selenic, identity, language, idioma, character, transformation 